\title{
Perlindungan Hukum Bagi Pengguna Pinjaman Online Terkait Bunga Pinjaman Dan Hak-Hak Pribadi Pengguna
}

\section{Dewa Ayu Trisna Dewi1,Ni Ketut Supasti Darmawan²}

1Direktorat Hak Cipta Dan Desain Industri Kementerian Hukum dan HAM RI, E-mail: trisnadewi95@yahoo.com

2Fakultas Hukum Universitas Udayana, E-mail: supasti_dharmawan@unud.ac.id

\begin{tabular}{l}
\hline Info Artikel \\
Masuk: 10 April 2021 \\
Diterima : 22 Juni 2021 \\
Terbit : 29 Juni 2021 \\
Keywords : \\
legal protection, online loan \\
users, Fintech \\
\\
Corresponding Author: \\
Dewa Ayu Trisna Dewi, \\
Email: \\
trisnadewi95@yahoo.com \\
DoI : \\
Perlindungana \\
Fintech
\end{tabular}

\begin{abstract}
The purpose of writing is to find out and analyze the interest arrangements on online loans at fintech companies and legal protection for the personal rights of online loan service users according to laws and regulations. Normative legal research methods. The approach used is a statutory approach and a historical approach. The technique of collecting legal materials uses literature study techniques. All legal materials that have been collected are then analyzed descriptively. The results of this study conclude that: first, the maximum interest arrangement on online loans at fintech companies is 0.8 percent per day and cannot exceed that number and must be written in the agreement, whereas if the amount of interest is not regulated in the agreement, the interest rate refers to Article 1250 KUHPerdata jo State Gazette No.22 / 1948 (s.No.22 / 1848), namely $6 \%$ per year. Second, legal protection for the personal rights of online loan service users according to the laws and regulations is through preventive protection and repressive protection, besides that, violations of the personal rights of online loan service users can be subject to sanctions in the form of administrative sanctions and criminal sanctions as such. regulated in the Consumer Protection Act, the ITE Law and the Human Rights Law.
\end{abstract}




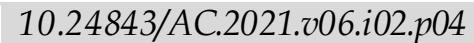

\section{Pendahuluan}

Berkembangnya informasi dan teknologi yang sangat dinamis sangat berpengaruh terhadap gaya hidup masyarakat, termasuk yang berkaitan dengan keuangan, salah satunya financial technology atau Fintech. ${ }^{1}$ Fintech adalah teknologi yang memanfaatkan perkembangan teknologi informasi berupa layanan pada lini industri keuangan. Financial Technology (Fintcech) atau teknologi finansial merupakan "innovation in financial services" sebagaimana menurut The National Digital Research Centre (NDRC), bahwa Fintech merupakan suatu inovasi pada sektor finansial yang mendapat sentuhan teknologi modern. ${ }^{2}$ International Organization of Securities Commision (IOSCO) mendefinisikan istilah Fintech sebagai model bisnis yang inovatif dengan teknologi yang berpotensi mengubah industri jasa keuangan. ${ }^{3}$ Menurut Fintech Weekly, bahwa Fintech adalah lini bisnis yang menggunakan software (perangkat lunak) dalam penyediaan layanan keuangannya. ${ }^{4}$

Menurut PBI (Peraturan Bank Indonesia) No.19/12/PBI/2017 tentang Penyelenggaraan Teknologi Finansial (PBI Fintech) pada Pasal 1 ayat (1) menentukan, bahwa "Teknologi Finansial adalah penggunaan teknologi dalam sistem keuangan yang menghasilkan produk, layanan, teknologi, dan/atau model bisnis baru serta dapat berdampak pada stabilitas moneter, stabilitas sistem keuangan, dan/atau efisiensi, kelancaran, keamanan, dan keandalan sistem pembayaran." Fintech adalah penerapan dan pemanfatan teknologi untuk peningkatan terhadap layanan jasa perbankan dan keuangan, yang biasanya ditangani oleh startup (perusahaan rintisan) dengan menggunakan teknologi berupa perangkat lunak (software), internet, komunikasi, dan komputerisasi terkini dengan tujuan menghemat waktu pada proses pembayaran dan memungkinkan konsumen untuk melakukan kegiatan finansial

\footnotetext{
1 Novita, Windy Sonya \& Moch. Najib Imanullah. (2020). Aspek Hukum Peer To Peer Lending (Identifikasi Permasalahan Hukum Dan Mekanisme Penyelesaian). Jurnal Privat Law, 3(1),151157, h.151. DOI: https:/ / doi.org/10.20961/privat.v8i1.40389

2 Santi, E., Budiharto, B., \& Saptono, H. (2017). Pengawasan Otoritas Jasa Keuangan Terhadap Financial Technology (Peraturan Otoritas Jasa Keuangan Nomor 77/POJK.01/2016). Diponegoro law iournal, 6(3), 1-20, h.2.

3 Wulan,V. R. (2017). Financial technology (fintech) a new transaction in future. Journal Electrical Engineering and Computer Sciences, 2(1), 177-182, h.178.

4 Otoritas Jasa Keuangan. (2017). Kajian Perlindungan Konsumen Sektor Jasa Keuangan: Perlindungan Konsumen pada Fintech. Jakarta: Departemen Perlindungan Konsumen.h.2.
} 
lainnya seperti menabung, melakukan investasi atau melakukan pembayaran. ${ }^{5}$

Salah satu bentuk fintech adalah Peer to peer lending yang merupakan layanan pinjam meminjam uang berbasis teknologi informasi antara Penerima dan Pemberi Pinjaman, atau pendanaan gotong royong online, yang juga dikenal sebagai pinjaman online. Pinjaman online melalui peer to peer lending, menjadikan masyarakat yang membutuhkan dana dengan nominal kecil dapat memperoleh pinjaman tanpa perlu mengajukan kredit kepada bank, dimana hal tersebut dirasakan lebih efisien dan sesuai dengan kebutuhan masyarakat karena persyaratan yang mudah dan tanpa perlu adanya jaminan. Layanan peer to peer lending ini, dapat diakses oleh masyarakat melalui aplikasi secara cepat, kapan dan dimana saja. Hal ini tentu berbeda dengan fasilitas kredit yang ditawarkan oleh bank, dimana calon nasabah harus mengajukan kredit terlebih dahulu dengan memberikan jaminan, baru kemudian dilakukan perjanjian kredit antara bank dengan nasabah. ${ }^{6}$

Saat ini pertumbuhan pinjaman online semakin marak, dalam waktu dua tahun perusahaan fintech yang menawarkan pinjaman online telah bermunculan ribuan perusahaan. Menurut data dari Otoritas Jasa Keuangan (OJK) menunjukkan, bahwa jumlah fintech tercatat pada Januari 2021 sebanyak 148, hal ini tercatat mengalami penurunan jika dibandinkgan pada awal tahun 2020 yang mencapai 164 platform,7 belum lagi dengan jumlah fintech illegal yang jumlahnya ribuan.

Pinjaman online memberikan penawaran dengan banyak fitur yang menguntungkan konsumen dibandingkan perbankan, sehingga seseorang yang ingin mendapatkan pinjaman, kini cukup mengunduh aplikasi atau mengkases website penyedia layanan pinjaman, mengisi data dan mengupload dokumen yang dibutuhkan dan dalam waktu yang singkat, uang pinjaman akan langsung masuk ke dalam rekening peminjam. Kemudahan-kemudahan yang diberikan fitur pinjaman online pada fintech ini, juga memiliki sisi negatif, seperti begitu mudahnya tersebar data pribadi peminjam karena proses verifikasi pinjaman online yang dilakukan secara online juga. Selain itu pada saat verifikasi data, pihak dari pinjaman online akan meminta akses semua data yang ada di smartphone si peminjam dan tentunya hal ini beresiko tinggi terhadap penyalahgunaan data. Permintaan data pribadi konsumen pinjaman online pada dasarnya dibutuhkan untuk melakukan assesement kepada calon peminjam dan untuk memberikan keyakinan bahwa peminjam uang adalah orang yang namanya tercantum dalam aplikasi, namun terkadang dalam beberapa kasus, akses kontak ini malah dimanfaatkan ketika melakukan penagihan.

Untuk memberikan perlindungan kepada konsumen, maka pada tahun 2016 OJK menerbitkan peraturan baru yaitu POJK No. 77/ POJK.01/2016 Tentang Layanan Pinjam Meminjam Berbasis Teknologi Informasi dan diikuti dengan POJK No. 13/POJK.02/2018 tentang Inovasi Keuangan Digital di Sektor Jasa Keuangan. Kedua

${ }^{5}$ Imam, Nofie. (2016). Financial Technology dan Lembaga Keuangan, Yogyakarta: Gathering Mitra Linkage Bank Syariah Mandiri, h.6.

6 Prilliasari, E. (2019).Pentingnya Perlindungan Data Pribadi Dalam Transaksi Pinjaman Online. Majalah Hukum Nasional, 49(2), 1-27. DOI: https:/ / doi.org/10.33331/mhn.v49i2.44

7 Rahardyan, Aziz. (2021). Januari 2021, FintechiP2P Resmi OJK Tinggal 148 Platform. Ini Daftarnya.Available from: https://finansial.bisnis.com/read/20210128/563/1349235/januari-2021-fintech-p2p-resmi-ojktinggal-148-platform-ini-daftarnya.(Diakses 18 Maret 2021) 
peraturan ini selanjutnya dijadikan dasar terhadap pengawasan dan pengaturan mengenai fintech.

Diterbitkannya Peraturan OJK tersebut, ternyata belum cukup untuk mencegah lahirnya perusahaan fintech illegal atau yang tidak mendaftarkan pada OJK. Menurut Pasal 7 POJK No. 77/ POJK.01/2016 menentukan, bahwa: "Penyelenggara wajib mengajukan pendaftaran dan perijinan kepada OJK", kemudian pada Pasal 1 ayat (6) POJK No. 77/ POJK.01/2016 menentukan, bahwa "Penyelenggara Layanan Pinjam Meminjam Uang Berbasis Teknologi Informasi yang selanjutnya disebut Penyelenggara adalah badan hukum Indonesia yang menyediakan, mengelola, dan mengoperasikan Layanan Pinjam Meminjam Uang Berbasis Teknologi Informasi." Selanjutnya pada Pasal 8 ayat (2) POJK No. 77/ POJK.01/2016 menentukan, bahwa "Penyelenggara yang telah melakukan kegiatan Layanan Pinjam Meminjam Uang Berbasis Teknologi Informasi sebelum peraturan OJK ini diundangkan, harus mengajukan permohonan pendaftaran kepada OJK paling lambat 6 (enam) bulan setelah peraturan OJK ini berlaku." Berdasarkan ketentuan dari beberapa pasal tersebut POJK mewajibkan kepada perusahaan fintech untuk mendaftarkan perusahannya kepada OJK, namun dari peraturan-peraturan yang dikeluarkan OJK tersebut tidak ditemukan sedikitpun sanksi terkait tidak didaftarkannya perusahaanperusahaan fintech tersebut, selain itu juga peraturan tersebut tidak mengatur mengenai batasan bunga pinjaman.

Tidak adanya sanksi terkait perusahaan-perusahaan fintech yang tidak mendaftarkan perusahaan pada OJK ditengarai menjadi salah satu sebab tumbuh suburnya fintech illegal. Hal ini tentu saja dapat mengakibatkan masalah, dimana perusahaan fintech yang tidak terdaftar pada OJK tersebut juga menyalurkan pinjaman online kepada masyarakat. Adanya pinjaman online dari perusahaan fintech ilegal ini tentu saja dapat merugikan masyarakat, dimana banyak terjadi pelanggaran. Beberapa pelanggaran yang dilakukan oleh pinjaman online ilegal tersebut adalah cara penagihan yang tidak sesuai dengan ketentuan, beban bunga yang tidak wajar, sampai pada penyebaran informasi data pribadi pengguna. ${ }^{8}$

Tidak hanya itu beberapa pelanggaran lain juga banyak ditemukan seperti adanya teror dan pengancaman saat penagihan, fitnah, pelecehan seksual hingga peminjaman di tempat lain yang dilakukan oleh sejumlah perusahaan peminjaman online dengan menggunakan KTP peminjam (korban) sehingga tagihan dan bunga pinjaman kemudian akan dibebankan kepada peminjam (korban). Dari adanya pelanggaran tersebut terdapat dampak yang ditimbulkan seperti pernah terjadi kasus sopir taksi yang meninggal gantung diri karena tidak mampu mengembalikan pinjaman akibat bunga yang terlalu tingi, kemudian kasus lainnya seperti peminjam yang kehilangan pekerjaan dikarenakan pihak pinjaman online menghubungi atasan tempat peminjam bekerja, sebagai salah satu akibat pihak pinjaman online yang dapat mengakses daftar kontak peminjam. ${ }^{9}$

\footnotetext{
8 Anonim. (2019). Maraknya Kasus Pinjaman Online Dan Penyebaran Data Nasabah. CNN Indonesia. Available from: URL: https:/ / www.cnnindonesia.com/ekonomi/20190326134104297-380774/maraknya-kasus-pinjaman-online-dan-penyebaran-data-nasabah.(Diakses tanggal 18 Maret 2020).

${ }^{9}$ Kencana, M.R.B. (2019). LBH Jakarta: Terror Utang Pinjaman Online adalah Pelanggaran
} 
Pelanggaran-pelanggaran yang terjadi tersebut jika dikaitkan dengan Hak Asasi Manusia (HAM), tentu saja telah terjadi pelanggaran HAM, yaitu pada Pasal 29 ayat (1) dan Pasal 30 Undang-Undang Nomor 39 Tahun 1999 Tentang Hak Asasi Manusia (selanjutnya disingkat UU HAM), sebagaimana ditentukan: Pasal 29 (1), bahwa “ Setiap orang berhak atas perlindungan diri pribadi, keluarga, kehormatan, martabat, dan hak miliknya." Selanjutnya pada Pasal 30, bahwa "Setiap orang berhak atas rasa aman dan tenteram serta perlindungan terhadap ancaman ketakutan untuk berbuat atau tidak berbuat sesuatu."

Berdasarkan dengan hal tersebut, diperlukan upaya dari pemerintah untuk menndaklanjuti permasalahan pinjaman online dari perusahaan fintech yang tidak terdaftar pada OJK/ilegal. Menurut apa yang diuraikan diatas terkait pinjaman online illegal, maka terdapat dua rumusan masalah atas penelitian ini, yaitu bagaimana pengaturan bunga pada pinjaman online di perusahaan fintech? Bagaimana pelindungan hukum terhadap hak-hak pribadi pengguna layanan sebagai konsumen pinjaman online menurut Peraturan Perundang-undangan?

Adapun tujuan dari penelitian ini ada dua, yaitu pertama, untuk mengetahui dan menganalisis mengenai pengaturan bunga pada pinjaman online di perusahaan fintech. Kedua, untuk mengetahui dan menganalisis mengenai pelindungan hukum terhadap hak-hak pribadi pengguna layanan sebagai konsumen pinjaman online menurut Peraturan Perundang-undangan.

Terdapat penelitian terdahulu yang memiliki kemiripan dengan penelitian ini, yaitu antara lain :

1. Jurnal berjudul "Perlindungan Hukum Terhadap Pengguna Pinjaman Online (Pinjol) Ilegal" oleh Rayyan Sugangga dan Erwin Hari Santoso dari Sekolah Tinggi Ilmu Ekonomi Indonesia Malang pada tahun 2020 yang meneliti mengenai keabsahan pinjaman melalui pinjol illegal dan perlindungan hukum terhadap pengguna. Kesimpulan yang didapatkan adalah pertama, meskipun pinjol ilegal, namun perjanjian pinjam meminjam antara pinjol ilegal dan pengguna tetap berlaku, artinya pengguna tidak dapat mengesampingkan kewajiban membayar hutang dengan alasan karena meminjam di perusahaan pinjol ilegal. Kedua, mengalihkan fokus untuk mengambil langkah-langkah preventif seperti lebih banyak melakukan edukasi dan sosialisasi kepada masyarakat, dengan tujuan semakin banyak masyarakat yang paham bagaimana memilih layanan pinjol yang kompeten serta memahami risiko-risiko yang mungkin terjadi saat menggunakan layanan pinjol. ${ }^{10}$

2. Jurnal berjudul "Perlindungan Hukum Terhadap Data Pribadi Peminjam Dalam Layanan aplikasi Pinjaman Online" oleh Ni Nyoman Ari Diah Nurmantari dan Nyoman A. Martana dari Universitas Udayana pada tahun 2019 yang meneliti mengenai Perlindungan hukum terhadap data pribadi peminjam dalam layanan

HAM.

https:/ / www.liputan6.com/bisnis/read/3887661/lbh-jakarta-teror-utang-pinjaman-onlineadalah-pelanggaran-ham. (Diakses tanggal 18 Maret 2021).

10 Sugangga, R. \& Erwin Hari Santoso. (2020). Perlindungan Hukum Terhadap Pengguna Pinjaman Online (Pinjol) Ilegal. PAJOUL (Pakuan Justice Journal Of Law), 1(1), 47-61. 
aplikasi pinjaman online, dan sanksi terhadap pelanggaran data pribadi. Kesimpulan yang didapatkan bahwa, perlindungan hukum dan sanksi bagi pelanggaran data pribadi telah diatur dalam UU No. 11 Tahun 2008 dan perubahannya tentang Informasi dan Transaksi Elektronik, namun secara khusus mengenai perlindungan hukum dan sanksi pelanggaran data pribadi dalam layanan pinjaman online telah tercantum dalam Peraturan Otoritas Jasa Keuangan No. 77/POJK.01/2016 tentang Layanan Pinjam Meminjam Uang Berbasis Teknologi Informasi, yang ditegaskan pada Pasal 26 bahwa pihak penyelenggara bertanggung jawab menjaga kerahasiaan, keutuhan dan ketersediaan data pribadi pengguna serta dalam pemanfaatannya harus memperoleh persetujuan dari pemilik data pribadi kecuali ditentukan lain oleh ketentuan peraturan perundangundangan. ${ }^{11}$

Kedua tulisan tersebut memiliki pokok permasalahan yang berbeda dengan tulisan ini, dimana tulisan ini memfokuskan pada pengaturan bunga pada pinjaman online di perusahaan fintech dan pelindungan hukum terhadap hak-hak pribadi pengguna layanan sebagai konsumen pinjaman online menurut Peraturan Perundang-undangan.

\section{Metode Penelitian}

Metode penelitian memuat jenis penelitian hukum normatif, karena fokus kajian berangkat dari kekosongan norma. Pendekatan yang digunakan adalah pendekatan perundang-undangan dan pendekatan sejarah. Teknik pengumpulan bahan hukum menggunakan teknik studi kepustakaan. Sumber bahan hukum terdiri dari sumber hukum primer dan sekunder. Seluruh bahan hukum yang telah terkumpul, selanjutnya dianalisis secara deksriptif.

\section{Hasil Dan Pembahasan}

\subsection{Pengaturan Bunga Pada Pinjaman Online Di Perusahaan Fintech}

Financial Technologi atau fintech dianggap sebagian besar orang adalah layanan pinjaman online. Fintech merupakan teknologi yang dapat memfasilitasi kebutuhan finansial masa kini dan membawa perubahan bagi kehidupan masyarakat melalui berbagai bentuk, menyesuaikan dengan kebutuhan masyarakat. Menurut Bank Indonesia, fintech dapat dibagi menjadi: 12

\section{Peer to Peer Lending atau Crowdfunding}

Peer to peer lending atau Crowdfunding yaitu sebuah marketplace yang digunakan untuk mempertemukan peminjam dan pemberi pinjaman yang merupakan perseorangan bukan lembaga dengan prosedur yang lebih sederhana dan tidak

11 Nurmantari, Ni Nyoman Ari Diah; Martna, Nyoman A. (2019). Perlindungan Hukum Terhadap Data Pribadi Peminjam Dalam Layanan aplikasi Pinjaman Online. Kertha Wicara: Journal Ilmu Hukum, 8(12).

12 Ginantra, Ni Luh Wiwik Sri Rahayu. (2020). Teknologi Finansial: Sistem Finansial Berbasis Teknologi Di Era Digital. Medan: Yayasan Kita Menulis.h. 14. 
berbelit-belit, serta dapat diselesaikan dalam waktu kurang dari seminggu dan lebih terjangkau dengan pemberian bunga kompetitif. Sistem ini juga memberikan kemudahan bagi para UMKM (Usaha Mikro Kecil Menengah) untuk mendapatkan modal sehingga dapat mengembangkan usahanya dan dapat diakses dari mana saja dan kapan saja

\section{Market Aggregator}

Market aggregator adalah sebuah situs yang menyajikan berbagai informasi terkait keuangan kepada pengguna dengan memberikan perbandingan berupa layanan yang dimiliki oleh asuransi, investasi, kartu kredit dan layanan keuangan lainnya, sehingga dapat mengetahui kekurangan dan kelebihan dari produk-produk layanan keuangan yang disediakan oleh berbagai bank.

\section{Risk and Investment Management}

Risk and Investment Management adalah fintech yang berfungsi untuk mengatur rencana keuangan untuk berbagai kebutuhan jangka pendek maupun jangka Panjang, dimana sebelumnya hal tesebut hanya dapa dilakukan kepada konsultan dan juga perencana keuangan.

\section{Payment, Settlement and Clearing}

Payment, settlement, and clearing adalah fintech yang dipergunakan untuk melakukan transaksi keuangan secara online, sehingga seseorang tidak perlu lagi menggunakan uang tunai untuk melakukan transaksi.

Berdasasarkan klasifkasi fintech dari Bank Indonesia tersebut, maka pinjaman online merupakan Peer to Peer Lending atau Crowdfunding yang pengawasannya dibawah OJK. Berdasarkan Pasal 6 Undang-Undang Nomor 21 Tahun 2011 Tentang Otoritas Jasa Keuangan (selanjutnya disingkat UU OJK) menentukan, bahwa:

"OJK melaksanakan tugas pengaturan dan pengawasan terhadap:

1. kegiatan jasa keuangan di sektor Perbankan;

2. kegiatan jasa keuangan di sektor Pasar Modal; dan

3. kegiatan jasa keuangan di sektor Perasuransian, Dana Pensiun, Lembaga Pembiayaan, dan Lembaga Jasa Keuangan Lainnya."

Pengawasan khusus terkait pinjaman online juga diatur melalui Peraturan Otoritas Jasa Keuangan Nomor 77 /POJK.01/2016 tentang Layanan Pinjam Meminjam Uang Berbasis Teknologi Informasi. Menurut Pasal 1 ayat (6) POJK No. 77 /POJK.01/2016 menentukan bahwa: "Penyelenggara Layanan Pinjam Meminjam Uang Berbasis Teknologi Informasi yang selanjutnya disebut Penyelenggara adalah badan hukum Indonesia yang menyediakan, mengelola, dan mengoperasikan Layanan Pinjam Meminjam Uang Berbasis Teknologi Informasi." Pasal 2 ayat (2) POJK No.77/POJK.01/2016 menentukan, bahwa "Badan hukum Penyelenggara berbentuk: perseroan terbatas; atau koperasi." Selanjutnya pada Pasal 7 POJK No.77/POJK.01/2016 menentukan, bahwa "penyelenggara wajib mengajukan pendaftaran dan perijinan kepada OJK." Berdasarkan ketentuan tersebut, maka penyelenggara dalam pinjaman online harusnya badan hukum berbentuk PT ataupun koperasi dan wajib mendaftarkan dan mendapat ijin dari OJK.

Kemudahan pemberian dana pinjaman kepada debitur dengan ketentuan dan persyaratan yang mudah membuat banyak orang tertarik dan menjadi debitur. 
Banyaknya minat dari para debitur inilah, menyebabkan tumbuh pesatnya perusahaan pinjaman online, namun tidak diiringi dengan pendaftaran dan mengajukan ijin kepada OJK, sehingga perusahaan tersebut dapat dikatakan illegal. Perusahan pinjaman online jika dilihat dari karekteristiknya antara perusahaan legal dan illegal tentu saya memiliki perbedaan, adapun perbedaan tersebut akan dijelaskan pada table dibawah ini. ${ }^{13}$

Tabel 1

Perbandingan Karakteristik Pinjaman Legal dengan Pinjaman Ilegal

\begin{tabular}{|l|l|l|l|}
\hline No & \multicolumn{1}{|c|}{ Perihal } & \multicolumn{1}{|c|}{ Pinjaman Legal } & \multicolumn{1}{|c|}{ Pinjaman ilegal } \\
\hline \hline 1 & Status di OJK & $\begin{array}{l}\text { Melakukan pendaftran dan } \\
\text { perijinan ke OJK }\end{array}$ & $\begin{array}{l}\text { Tidak terdaftar dan tidak } \\
\text { memgajukan ijin ke OJK }\end{array}$ \\
\hline 2 & Aplikasi & $\begin{array}{l}\text { Aplikasi terdapat pada } \\
\text { Playstore/Appstrore dan ada } \\
\text { Logo OJK }\end{array}$ & $\begin{array}{l}\text { Aplikasi tidak terdapat } \\
\text { pada Playstore/Appstrore } \\
\text { dan tidak ada Logo OJK. } \\
\text { Pengguna melakukan } \\
\text { installasi menggunakan } \\
\text { APK }\end{array}$ \\
\hline 3 & $\begin{array}{l}\text { Metode } \\
\text { penawaran }\end{array}$ & $\begin{array}{l}\text { Promo iklan resmi } \\
\text { Kredit }\end{array}$ & $\begin{array}{l}\text { Memepgunakan broadcast } \\
\text { dokumen } \\
\text { pesan Wahts App, SMS }\end{array}$ \\
\hline 4 & Domisili & $\begin{array}{l}\text { Alamat dan kontak perusahaan } \\
\text { jelas }\end{array}$ & $\begin{array}{l}\text { Alamat dan konderung sangat mudah } \\
\text { perusahaan tidak jelas, } \\
\text { bahkan tidak ada. }\end{array}$ \\
\hline
\end{tabular}

Bermunculan fintech ilegal ini tentu saja dapat menimbulkan permasalah baru, apalagi belum adanya peraturan yang dapat mengatasi keberadan fintech ilegal. ${ }^{14}$ Bermunculan fintech ilegal ini tentu saja menimbulkan banyak persoalan baru terutama terkait tingkat suku bunga pinjaman yang tinggi. Pada Fintech berbasis pinjaman online yang telah terdaftar di OJK, tarif bunga maksimal yang dikenakan adalah 0,8 persen per hari. Hal ini merupakan bagian dari kode etik yang disusun oleh Asosiasi Fintech Pendanaan Bersama Indonesia (AFPI). ${ }^{15}$ Pemberian bunga maksimal yang tinggi dikarenakan kemudahan dalam pemberian dana pinjaman, sedangkan bagi pemberi pinjaman dikarenakan pinjaman ini memiliki resiko yang tinggi pada pengembaliannya dan tidak adanya jaminan.

AFPI merupakan wadah yang menaungi para penyelengara Fintech Peer to Peer Lending berdasarkan surat No. S-5/D.05/2019 yang dikeluarkan oleh OJK. AFPI menjadi

13 Sugangga, R. \& Erwin Hari Santoso. Op.Cit. h.47-61.

14 ____. (2020).3 Isu Hukum Bisnis Yang Patut Dipantau Di Awal 2020. Available from: https://www.kai.or.id/berita/16627/3-isu-hukum-bisnis-yang-patut-dipantau-di-awal2020.html. (diakses 20 Maret 2021).

15 Wicaksono, Adhi. (2019). OJK Tegaskan Bunga Pinjol Tak Boleh Lebih Dari 0.8 Persen. Available from: https:/ / www.cnnindonesia.com/ekonomi/20190923140514-78-432990/ojktegaskan-bunga-pinjol-tak-boleh-lebih-dari-08-persen. (diakses 21 Maret 2021). 
asosiasi resmi yang mengemban amanat dalam kegiatan peyelenggaraan layanan pinjaman berbasis teknologi di informasi. AFPI berfungsi sebagai lembaga riset kebijakan yang bertujuan mengembangkan sektor keuangan berbasis teknologi; sebagai penghubung lembaga fintech Internasional agar dapat menjalin hubungan dengan komunitas global; berkolaborasi dan berpartisipasi secara aktif dengan komunitas fintech di Indonesia memberikan edukasi, ilmu, mempromosikan, dan memajukan agenda-agenda dari teknologi finansial; mengawasi para penyelenggara fintech di Indonesia; mengadakan seminar dan memberikan sertifikat bagi para penyelenggara Fintech Peer to Peer Lending yang mengikuti seminar tersebut yang dimana sertifikat tersebut digunakan sebagai syarat mendaftarkan organisasinya secara resmi di OJK. AFPI ditunjuk oleh OJK untuk membantu OJK dalam mengatasi banyaknya peyelenggara fintech ilegal yang membuka layanan jasa keuangan Peer to Peer Lending. Fintech ilegal ini menetapkan suku bunga pinjaman suku bunga pinjaman dengan sangat tinggi dan membuat banyak debitur terjerat dan disertai dengan cara penagihan dengan cara yang tidak layak dan menyebarkan data pribadi debitur secara sembarangan. Bahkan, penyelenggara-penyelenggara Fintech Pendanaan Peer to Peer Lending yang sudah terdaftar di OJK namun belum terverifikasi, juga sering memberikan pinjaman dengan memberikan suku bunga pinjaman yang tinggi. ${ }^{16}$

AFPI mengeluarkan kebijakan bahwa batasan bunga maksimum yaitu sebesar 0,8\% per hari dan hal ini tidak diatur oleh OJK. Menurut Kitab Undang-undang Hukum Perdata (selanjutnya disingkat KUH Perdata) Pasal 1767, bahwa:

"Ada bunga menurut penetapan undang-undang, ada pula yang ditetapkan dalam perjanjian. Bunga menurut undang-undang ialah bunga yang ditentukan oleh undangundang. Bunga yang ditetapkan dalam perjanjian boleh melampaui bunga menurut undang-undang dalam segala hal yang tidak dilarang undang-undang. Besarnya bunga yang ditetapkan dalam perjanjian harus dinyatakan secara tertulis."

Selanjutnya pada Pasal 1768 KUHPerdata, yaitu: “Jika pemberi pinjaman memperjanjikan bunga tanpa menentukan besarnya, maka penerima pinjaman wajib membayar bunga menurut undang-undang."Berdasarkan ketentuan tersebut, maka pengenaan bunga pinjaman diperbolehkan melampaui besaran bunga menurut undang-undang, asalkan ditetapkan dalam perjanjian dan disepakati oleh para pihak, serta tidak bertentangan dengan undang-undang, namun apabila besaran bunga tidak diatur dalam perjanjian pinjam meminjam, maka penerima pinjaman hanya wajib membayar bunga menurut undang-undang, sebagaimana hal ini diatur pada Pasal 1250 KUHPerdata jo Lembaran Negara No.22/1948 (s. No.22/1848) yaitu 6\% pertahun.

\subsection{Perlindungan Hukum Terhadap Hak-Hak Pribadi Pengguna Layanan Sebagai Konsumen Pinjaman Online Menurut Peraturan Perundang-Undangan.}

Perlindungan hukum adalah perlindungan akan harkat dan martabat, serta pengakuan terhadap hak-hak asasi manusia yang dimiliki subjek hukum berdasarkan ketentuan hukum dari kesewenangan atau sebagai kumpulan peraturan atau kaidah yang akan

\footnotetext{
16 Tjandra, Antoni. (2020). Kekosongan Norma Penentuan Bunga Pinjaman Financial Technology Peer To Peer Lending. Jurnal Hukum Bisnis Bonum Commune, 3(1), 90-103. h.100-101. DOI: https:// doi.org/10.30996/jhbbc.v3i1
} 
dapat melindungi suatu hal dari hal lainnya. ${ }^{17}$ Perlindungan hukum juga merupakan tindakan atau upaya untuk melindungi masyarakat dari perbuatan sewenang-wenang oleh penguasa yang tidak sesuai dengan aturan hukum, untuk mewujudkan ketertiban dan ketenteraman sehingga memungkinkan manusia untuk menikmati martabatnya sebagai manusia. ${ }^{18}$

Terkait perlindungan hukum terhadap pengguna pinjaman online, POJK No.77/POJK.01/2016 mengatur mengenai hak-hak yang dimiliki oleh pengguna jasa pinjaman online, sebagaimana diuraikan pada kewajiban dan larangan penyelenggara pinjaman online, yaitu terdapat pada beberapa pasal, antara lain:

Pasal 30 Ayat (1): "Penyelenggara wajib menyediakan dan/atau menyampaikan informasi terkini mengenai Layanan Pinjam Meminjam Uang Berbasis Teknologi Informasi yang akurat, jujur, jelas, dan tidak menyesatkan."

Pasal 31 Ayat (1): "Penyelenggara wajib menyampaikan informasi kepada Pengguna tentang penerimaan, penundaan, atau penolakan permohonan Layanan Pinjam Meminjam Uang Berbasis Teknologi Informasi."

Pasal 32 Ayat (1): "Penyelenggara wajib menggunakan istilah, frasa, dan/atau kalimat yang sederhana dalam bahasa Indonesia yang mudah dibaca dan dimengerti oleh Pengguna dalam setiap Dokumen Elektronik."

Pasal 36 Ayat (1): "Dalam hal Penyelenggara menggunakan perjanjian baku, perjanjian baku tersebut wajib disusun sesuai dengan ketentuan peraturan perundang-undangan."

Pasal 36 Ayat (2): "Perjanjian baku sebagaimana dimaksud pada ayat (1) yang digunakan oleh Penyelenggara dilarang:

a. menyatakan pengalihan tanggung jawab atau kewajiban Penyelenggara kepada Pengguna; dan

b. menyatakan bahwa Pengguna tunduk pada peraturan baru, tambahan, lanjutan dan/atau perubahan yang dibuat secara sepihak oleh Penyelenggara dalam periode Pengguna memanfaatkan layanan."

Pasal 37 "Penyelenggara wajib bertanggung jawab atas kerugian Pengguna yang timbul akibat kesalahan dan/atau kelalaian, Direksi, dan/atau pegawai Penyelenggara."

Pasal 39 ayat (1) dan (2): "Penyelenggara dilarang dengan cara apapun, memberikan data dan/atau informasi mengenai Pengguna kepada pihak ketiga, kecuali Pengguna memberikan persetujuan secara elektronik; dan/atau diwajibkan oleh ketentuan peraturan perundang- undangan."

Pengguna jasa pinjaman online sebagai konsumen, memiliki hak-hak sebagaimana diatur pada Pasal 4 Undang-Undang Nomor 8 Tahun 1999 Tentang Perlindungan Konsumen (selanjutnya disingkat UU Perlindungan Konsumen) menentukan, bahwa: "Hak konsumen adalah :

1. hak atas kenyamanan, keamanan, dan keselamatan dalam mengkonsumsi barang dan/atau jasa;

${ }^{17}$ Hadjon, Philipus M. (1987) Perlindungan Hukum Bagi Rakyat di Indonesia. Surabaya: PT. Bina Ilmu, Surabaya.h. 25.

18Setiono. (2004) Rule of Law (Supremasi Hukum). Surakarta: Universitas Sebelas MaretSurakarta. h.3. 
2. hak untuk memilih barang dan/atau jasa serta mendapatkan barang dan/atau jasa tersebut sesuai dengan nilai tukar dan kondisi serta jaminan yang dijanjikan;

3. hak atas informasi yang benar, jelas, dan jujur mengenai kondisi dan jaminan barang dan/atau jasa;

4. hak untuk didengar pendapat dan keluhannya atas barang dan/atau jasa yang digunakan;

5. hak untuk mendapatkan advokasi, perlindungan, dan upaya penyelesaian sengketa perlindungan konsumen secara patut;

6. hak untuk mendapat pembinaan dan pendidikan konsumen;

7. hak untuk diperlakukan atau dilayani secara benar dan jujur serta tidak diskriminatif;

8. hak untuk mendapatkan kompensasi, ganti rugi dan/atau penggantian, apabila barang dan/atau jasa yang diterima tidak sesuai dengan perjanjian atau tidak sebagaimana mestinya;

9. hak-hak yang diatur dalam ketentuan peraturan perundang-undangan lainnya."

Menurut POJK 77/POJK.01/2016 Pasal 29 menentukan, bahwa: "Penyelenggara wajib menerapkan prinsip dasar dari perlindungan Pengguna yaitu: transparansi; perlakuan yang adil; keandalan; kerahasiaan dan keamanan data; dan penyelesaian sengketa Pengguna secara sederhana, cepat, dan biaya terjangkau." Berkenaan dengan hal tersebut, maka pelaku usaha yang melanggar hak-hak pengguna layanan pinjaman online sebagai konsumen dapat dikenai sanksi. Menurut Pasal 47 ayat (1) POJK 77/POJK.01/2016 "Atas pelanggaran kewajiban dan larangan dalam peraturan OJK ini, OJK berwenang mengenakan sanksi administratif terhadap Penyelenggara berupa: peringatan tertulis; denda, yaitu kewajiban untuk membayar sejumlah uang tertentu; pembatasan kegiatan usaha; dan pencabutan izin."

Pada dasarnya, hubungan antara konsumen dan pelaku usaha adalah hubungan hukum keperdataan, tetapi UU Perlindungan Konsumen juga mengenakan sanksi pidana bagi pelanggar hak-hak konsumen, sebagaimana UU Perlindungan Konsumen Pasal 45 Ayat (3) menentukan, bahwa "Penyelesaian di luar pengadilan sebagaimana dimaksud pada Ayat 2 tidak menghilangkan tanggung jawab pidana sebagaimana diatur dalam undang-undang. ${ }^{19}$ Hubungan antara pengguna dan penyelenggara layanan pinjaman online diikat oleh suatu perjanjian yang menggunakan media elektronik. Terkait perlindungan terhadap pengguna layanan pinjaman online Undang-Undang Nomor 19 Tahun 2016 Tentang Perubahan Atas Undang-Undang Nomor 11 Tahun 2008 Tentang Informasi Dan Transaksi Elektronik (selanjutnya disingkat UU ITE) mengaturnya dalam beberapa pasal, antara lain:

Pasal 26 ayat (1) dan (2):

(1) "Kecuali ditentukan lain oleh peraturan perundang-undangan, penggunaan setiap informasi melalui media elektronik yang menyangkut data pribadi seseorang harus dilakukan atas persetujuan Orang yang bersangkutan."

(2) "Setiap Orang yang dilanggar haknya sebagaimana dimaksud pada ayat (1) dapat mengajukan gugatan atas kerugian yang ditimbulkan berdasarkan

\footnotetext{
${ }^{19}$ Susanto, Happy. (2008). Hak-Hak Konsumen Jika Dirugikan. Jakarta: Visimedia. h.41.
} 
Undang-Undang ini."

Pasal 45 ayat (3):

"Setiap Orang yang dengan sengaja dan tanpa hak mendistribusikan dan/atau mentransmisikan dan/atau membuat dapat diaksesnya Informasi Elektronik dan/atau Dokumen Elektronik yang memiliki muatan penghinaan dan/atau pencemaran nama baik sebagaimana dimaksud dalam Pasal 27 ayat (3) dipidana dengan pidana penjara paling lama 4 (empat) tahun dan/atau denda paling banyak Rp750.000.000,00 (tujuh ratus lima puluh juta rupiah)."

Pasal 45B:

"Setiap Orang yang dengan sengaja dan tanpa hak mengirimkan Informasi Elektronik dan/atau Dokumen Elektronik yang berisi ancaman kekerasan atau menakut-nakuti yang ditujukan secara pribadi sebagaimana dimaksud dalam Pasal 29 dipidana dengan pidana penjara paling lama 4 (empat) tahun dan/atau denda paling banyak Rp750.000.000,00 (tujuh ratus lima puluh juta rupiah)."

Adanya aturan dengan tujuan memberikan perlindungan kepada pengguna layanan pinjaman online ternyata belum mampu mencegah terjadinya pelanggaran terhadap pengguna layanan pinjaman online. Pelanggaran tersebut kini ternyata telah mengarah kepada ancaman dan teror terhadap para pengguna layanan pinjaman online yang dianggap lalai dalam melakukan pembayaran. Deklarasi Universal Hak Asasi Manusia (DUHAM) menentukan, bahwa "tidak seorang pun boleh diganggu urusan pribadinya, keluarganya, rumah tangganya atau hubungan surat menyuratnya dengan sewenang-wenang; juga tidak diperkenankan melakukan pelanggaran atas kehormatan dan nama baiknya. Setiap orang berhak mendapat perlindungan hukum terhadap gangguan atau pelanggaran seperti ini." Isi dari DUHAM tersebut pun telah diturunkan dalam UU HAM.

Pada perkembangannya, privacy tidak saja dilindungi oleh hukum tapi juga termasuk oleh norma-norma budaya, etika dan praktik-praktik bisnis/profesional.20 Pelanggaran HAM dapat terjadi juga pada ancaman pelaporan kepada pihak kepolisian terkait ketidakmampuan pengguna layanan pinjaman online dalam melakukan pembayaran. Pasal 19 Ayat (2) UU HAM menentukan, bahwa "Tidak seorangpun atas putusan pengadilan boleh dipidana penjara atau kurungan berdasarkan atas alasan ketidakmampuan untuk memenuhi suatu kewajiban dalam perjanjian utang piutang." Isi pasal tersebut berarti bahwa ketidakmampuan membayar pinjaman tidak dapat dijadikan alasan dalam melakukan pemidanaan terhadap pengguna layanan pinjaman online. Dalam hal ini Anggota Komisioner Komisi Hak Asasi Manusia (Komnas HAM), Mohammad Choirul Anam menyatakan bahwa penegak hukum tidak dapat menjerat pengguna layanan sebagai debitur yang tidak mampu membayar pinjaman tersebut mengingat, permasalahan tersebut termasuk kategori perjanjian utang-piutang bukan ranah pidana melainkan perdata. Apabila, aparat penegak hukum tetap memberikan sanksi pidana kepada debitur maka tindakan tersebut merupakan pelanggaran terhadap undang- undang. ${ }^{21}$

${ }^{20}$ Astuti, Sri Ayu. (2020). Era Disrupsi Teknologi 4.0 dan Aspek Perlindungan Data Hak Pribadi. PAJOUL (Pakuan Justice Journal of Law), 1(1), h.4.

21 . (2020). Gagal Bayar Pinjaman Fintech, Bisakah Dikenakan Pidana. Available from: https://www.kai.or.id/berita/16910/gagal- bayar-pinjaman-fintech-bisakah-dikenakanpidana.html. (diakses 23 Maret 2021) 
Walaupun tidak terdapat sanksi dalam UU HAM, namun menurut penjelasan UU HAM pelanggaran terhadap HAM dapat dikenakan sanksi pidana, perdata dan/atau administratif, yaitu menenetukan:

“Undang-undang tentang Hak Asasi Manusia ini adalah merupakan payung dari seluruh peraturan perundang-undangan tentang hak asasi manusia. Oleh karena itu, pelanggaran baik langsung maupun tidak langsung atas hak asasi manusia dikenakan sanksi pidana, perdata, dan atau administratif sesuai dengan ketentuan peraturan perundang-undangan."

Aturan-aturan yang dibentuk tersebut berupaya memberikan perlindungan terhadap pelanggaran yang dilakukan oleh penyelenggara layanan pinjaman online berupa sanksi pidana ataupun denda. Akan tetapi perlu adanya upaya pemerintah untuk mencegah dan menangani berbagai kasus kejahatan serta penyelesaian sengketa yang terjadi antara penyelenggara dan pengguna layanan pinjaman online. Adapun bentuk perlindungan tersebut dapat dibagi 2, yaitu:

1. Perlindungan preventif, yaitu perlindungan hukum yang bertujuan untuk mencegah terjadinya sengketa, salah satunya melalui upaya sosialisasi yang dilakukan oleh pihak OJK bekerjasama dengan Kementerian Komunikasi dan Informatika dalam rangka memberikan pengetahuan kepada masyarakat mengenai pinjaman online dari berbagai aspek baik legalitas, suku bunga, metode penawaran dan sebagainya. Selain itu juga perlu melakukan koordinasi dengan Kementerian Hukum dan HAM dalam hal ini Badan Pembinaan Hukum Negara (BPHN) agar dapat membantu dalam memberikan penyuluhan hukum mengenai dampak dari penggunaan pinjaman online illegal terutama yang berkaitan dengan pelanggaran HAM.

2. Perlindungan refresif adalah perlindungan hukum yang tujuannya untuk menyelesaikan sengketa, apabila ada pihak yang merasa dirugikan dapat mengajukan pengaduan agar sengketa yang terjadi dapat segera terselesaikan.

Selanjutnya menurut Pasal 39 POJK Nomor 1/POJK.07/2013 Tahun 2013 Tentang Perlindungan Konsumen Sektor Jasa Keuangan (selanjutnya disingkat POJK No.1/POJK.07/2013) bahwa:

Ayat (1) “Dalam hal tidak mencapai kesepakatan penyelesaian pengaduan, Konsumen dapat melakukan penyelesaian sengketa di luar pengadilan atau melalui pengadilan."

Ayat (2) "Penyelesaian sengketa di luar pengadilan sebagaimana dimaksud pada ayat (1) dilakukan melalui lembaga alternatif penyelesaian sengketa."

Ayat (3) "Dalam hal penyelesaian sengketa tidak dilakukan melalui lembaga alternatif penyelesaian sengketa sebagaimana dimaksud pada ayat (2), Konsumen dapat menyampaikan permohonan kepada Otoritas Jasa Keuangan untuk memfasilitasi penyelesaian pengaduan Konsumen yang dirugikan oleh pelaku di Pelaku Usaha Jasa Keuangan."

\section{Kesimpulan}


Hasil penelitian ini menyimpulkan bahwa: pertama, pengaturan bunga maksimal pada pinjaman online di perusahaan fintech adalah 0,8 persen perhari dan tidak boleh melebihi angka tersebut, sebagaimana hal tesebut dalam kode etik AFPI dan harus tertulis dalam perjanjian sedangkan jika besaran bunga tidak diatur dalam perjanjian, maka besaran bunga mengacu pada Pasal 1250 KUHPerdata jo Lembaran Negara No.22/1948 (s. No.22/1848) yaitu 6\% pertahun. Kedua, pelindungan hukum terhadap hak-hak pribadi pengguna layanan sebagai konsumen pinjaman online menurut Peraturan Perundang-undangan adalah melalui Perlindungan preventif dan Perlindungan refresif, selain itu juga terkait pelanggaran terhadap hak-hak pribadi pengguna layanan pinjaman online dapat dikenakan sanksi berupa sanksi admistratif dan sanksi pidana sebagaiamana hal tersebut diatur dalam UU Perlindungan Konsumen, UU ITE dan UU HAM.

\section{Daftar Pustaka / Daftar Referensi}

\section{Buku}

Ginantra, Ni Luh Wiwik Sri Rahayu. (2020).Teknologi Finansial: Sistem Finansial Berbasis Teknologi Di Era Digital. Medan: Yayasan Kita Menulis.

Hadjon, Philipus M. (1987) Perlindungan Hukum Bagi Rakyat di Indonesia. Surabaya: PT. Bina Ilmu.

Imam, Nofie. (2016). Financial Technology dan Lembaga Keuangan. Yogyakarta: Gathering Mitra Linkage Bank Syariah Mandiri.

Otoritas Jasa Keuangan. (2017). Kajian Perlindungan Konsumen Sektor Jasa Keuangan: Perlindungan Konsumen pada Fintech. Jakarta: Departemen Perlindungan Konsumen.

Setiono. (2004) Rule of Law (Supremasi Hukum). Surakarta: Universitas Sebelas Maret Surakarta.

Susanto, Happy. (2008). Hak-Hak Konsumen Jika Dirugikan. Jakarta: Visimedia.

\section{Jurnal}

Astuti, Sri Ayu. (2020). Era Disrupsi Teknologi 4.0 dan Aspek Perlindungan Data Hak Pribadi. PAJOUL (Pakuan Justice Journal of Law), 1(1).

Hartanto, Ratna dan Ramli, Juliyani Purnama. (2018). Hubungan Hukum Para Pihak Dalam Peer to Peer Lending. Jurnal Hukum IUS QUIA IUSTUM, 2(2).

Novita, Windy Sonya \& Moch. Najib Imanullah. (2020). Aspek Hukum Peer To Peer Lending (Identifikasi Permasalahan Hukum Dan Mekanisme Penvelesaian). Jurnal Privat Law, 3(1). DOI: https://doi.org/10.20961/privat.v8i1.40389 
Nurmantari, Ni Nyoman Ari Diah; Martna, Nyoman A. (2019). Perlindungan Hukum Terhadap Data Pribadi Peminjam Dalam Layanan aplikasi Pinjaman Online. Kertha Wicara: Journal Ilmu Hukum, 8.

Prilliasari, E. (2019).Pentingnya Perlindungan Data Pribadi Dalam Transaksi Pinjaman Online. Majalah Hukum Nasional, 49(2), 1 1-27. DOI: https://doi.org/10.33331/mhn.v49i2.44

Santi, E., Budiharto, B., \& Saptono, H. (2017). Pengawasan Otoritas Jasa Keuangan Terhadap Financial Technologv (Peraturan Otoritas Jasa Keuangan Nomor 77/POJK. 01/2016). Diponegoro law journal, 6(3).

Sugangga, R. \& Erwin Hari Santoso. (2020). Perlindungan Hukum Terhadap Pengguna Pinjaman Online (Pinjol) Ilegal. PAJOUL (Pakuan Justice Journal Of Law), 1(1).

Tjandra, Antoni. (2020). Kekosongan Norma Penentuan Bunga Pinjaman Financial Technology Peer To Peer Lending. Iurnal Hukum Bisnis Bonum Commune, 3(1). DOI: https://doi.org/10.30996/jhbbc.v3i1

Wulan, V. R. (2017). Financial technologu (fintech) a new transaction in future. Journal Electrical Engineering and Computer Sciences, 2(1).

\section{Online/World Wide Web:}

(2020). Gagal Bayar Pinjaman Fintech, Bisakah Dikenakan Pidana. Available from: https://www.kai.or.id/berita/16910/gagal- bayar-pinjaman-fintech-bisakahdikenakan- pidana.html. (diakses 23 Maret 2021)

(2020).3 Isu Hukum Bisnis Yang Patut Dipantau Di Awal 2020. Available from: https://www.kai.or.id/berita/16627/3-isu- hukum-bisnis-yang-patutdipantau-di-awal- 2020.html. (diakses 20 Maret 2021).

Anonim. (2019). Maraknya Kasus Pinjaman Online Dan Penyebaran Data Nasabah. CNN Indonesia. Available from: URL: https://www.cnnindonesia.com/ekonomi/20190326134104-297-380774/maraknyakasus-pinjaman-online-dan-penyebaran-data-nasabah. (Diakses tanggal 18 Maret 2020).

Kencana, M.R.B. (2019). LBH Jakarta: Terror Utang Pinjaman Online adalah Pelanggaran HAM. Liputan6.com. available from: URL: https://www.liputan6.com/bisnis/read/3887661/lbh-jakarta-teror- utangpinjaman-online-adalah-pelanggaran-ham. (Diakses tanggal 18 Maret 2021).

Rahardyan, Aziz. (2021). Januari 2021, Fintech P2P Resmi OJK Tinggal 148 Platform. Ini Daftarnya. Available from: https://finansial.bisnis.com/read/20210128/563/1349235/januari-2021-fintechp2p-resmi-ojk-tinggal-148-platform-ini-daftarnya. (Diakses 18 Maret 2021)

Wicaksono, Adhi. (2019). OJK Tegaskan Bunga PinjolTak Boleh Lebih Dari 0.8 Persen. Available from: https://www.cnnindonesia.com/ekonomi/20190923140514-78432990/ojk-tegaskan-bunga-pinjol-tak-boleh-lebih-dari-08-persen. (diakses 21 Maret 2021). 


\section{$\underline{\text { Peraturan Perundang-undangan }}$}

Kitab Undang-undang Hukum Perdata

Undang-Undang Nomor 39 Tahun 1999 Tentang Hak Asasi Manusia (Lembaran Negara Republik Indonesia Tahun 1999 Nomor 165, Tambahan Lembaran Negara Republik Indonesia Nomor 3886).

Undang-Undang Nomor 8 Tahun 1999 Tentang Perlindungan Konsumen (Lembaran Negara Republik Indonesia Tahun 1999 Nomor 42, Tambahan Lembaran Negara Republik Indonesia Nomor 3821).

Undang-Undang Nomor 19 Tahun 2016 Tentang Perubahan Atas Undang-Undang Nomor 11 Tahun 2008 Tentang Informasi Dan Transaksi Elektronik (Lembaran Negara Republik Indonesia Tahun 2016 Nomor 251, Tambahan Lembaran Negara Republik Indonesia Nomor 5952).

Undang-Undang Nomor 21 Tahun 2011 Tentang Otoritas Jasa Keuangan (Lembaran Negara Republik Indonesia Tahun 2011 Nomor 111, Tambahan Lembaran Negara Republik Indonesia Nomor 5253).

Peraturan Bank Indonesia Nomor 19/12/PBI/2017 Tentang Penyelenggaraan Teknologi Finansial (PBI Fintech)

Peraturan Otoritas Jasa Keuangan Nomor 1/POJK.07/2013 Tahun 2013 Tentang Perlindungan Konsumen Sektor Jasa Keuangan

Peraturan Otoritas Jasa Keuangan Nomor 77/ POJK.01/2016 Tentang Layanan Pinjam Meminjam Berbasis Teknologi Informasi

Peraturan Otoritas Jasa Keuangan Nomor 13/POJK.02/2018 tentang Inovasi Keuangan Digital di Sektor Jasa Keuangan 